\title{
Bioactivity comparison of extracts from various parts of common and tartary buckwheats: evaluation of the antioxidant- and angiotensin- converting enzyme inhibitory activities
}

\author{
Hweiyan Tsai ${ }^{1,2^{*}}$, Hweiwen Deng ${ }^{1}$, Shangheng Tsai ${ }^{1}$ and Yahsien Hsu ${ }^{1}$
}

\begin{abstract}
Background: Buckwheat flour and buckwheat sprouts possess antioxidant properties, and previous studies have reported on buckwheat flour displaying an inhibitory activity for angiotensin-I converting enzyme (ACE). Information is lacking on the bioactivity of other parts of the buckwheat, such as the seed hulls and plant stalks. This study investigates the ACE inhibitory activity and antioxidant activity of various parts of 2 types of buckwheat, namely, common buckwheat (Fagopyrum esculentum Moench) and tartary buckwheat (Fagopyrum tataricum Gaertn).

Results: The extract of common hulls extracted using 50\% (v/v)-ethanol solvent presented a remarkable inhibitory activity. The value of $\mathrm{IC}_{50}$ is $30 \mathrm{\mu g} \mathrm{m}^{-1}$. The extracts of both common and tartary hulls extracted using $50 \%(\mathrm{~V} / \mathrm{v})$ ethanol solvent demonstrated an antioxidant activity that is superior to that of other extracts.

Conclusion: This study determined that the ethanolic extract of the hulls of common buckwheat presented more favorable antioxidant and ACE inhibitory abilities. However, the correlation of antioxidant activity and ACE inhibitory activity for all 18 types of extracts is low. The ACE inhibitory activity could have been caused by a synergistic effect of flavonoids or from other unidentified components in the extracts. The ethanolic extract of common hulls demonstrated remarkable ACE inhibitory activity and is worthy of further animal study.
\end{abstract}

Keywords: Tartary buckwheat, Common buckwheat, ACE inhibition, Microplate fluometric assay

\section{Background}

Food is not only a source of energy and nutrition for maintenance and growth of the body but is also a source of bioactive compounds that have beneficial effects on humans. For example, common buckwheat (Fagopyrum esculentum) and tartary buckwheat (Fagopyrum tataricum) are traditional foodstuffs available worldwide. They are also essential as functional food resources because of the high polyphenol and mineral contents in the seed. Numerous previous studies have discussed the antioxidant properties of buckwheat flour and buckwheat sprouts [1-12]. Campbell [13] reported that

\footnotetext{
* Correspondence: annetsai@csmu.edu.tw

'Department of Applied Chemistry, Chung Shan Medical University, Taichung 402, Taiwan

${ }^{2}$ Clinical Laboratory, Chung Shan Medical University Hospital, Taichung 402,
} Taiwan

buckwheat comprises 3 classes of flavonoids: flavonols, anthocyanins, and C-glucosyl-flavones. ACEinhibitory activity of flavonoids isolated from other plants has been reported previously [14,15]. The only reports existent were of dipeptides from buckwheat flour displaying inhibitory activity for the angiotensin-I converting enzyme [16-18]. No information is available regarding the inhibitory activity of angiotensin-I converting enzymes in other parts of the buckwheat plant. From an agricultural perspective, identifying an alternative approach for using the entire buckwheat plant, such as the stalks, leaves, and hulls, is crucial. Therefore, the objective of this study was to evaluate systematically the ACE inhibitory activity and antioxidant activity of different parts and varieties of buckwheat, namely, common buckwheat (Fagopyrum esculentum 
Moench) and tartary buckwheat (Fagopyrum tataricum Gaertn).

\section{Results}

The IC $\mathrm{C}_{50}$ values of various extracts for ACE inhibition To ensure accurate function of the modified microplate fluormetric assay, we determined the $\mathrm{IC}_{50}$ for Captopril, a known ACE inhibitor. Captopril is a common orally administered ACE inhibitor used to treat hypertension and congestive heart failure. The measured $\mathrm{IC}_{50}$ was $1.9 \mathrm{ng} \mathrm{ml}^{-1}(8.7 \mathrm{nM})$, which was comparable to measurements shown in the literature (7 $\mathrm{nM})$ [19]. PihlantoLeppala et al. [19] determined ACE activity by measuring hippuric acid liberated from the reaction of hippuryl-L-histidyl-L-leucine and rabbit ACE with HPLC.

Table 1 shows the $\mathrm{IC}_{50}$ of various extracts for ACE inhibition. The rutin equivalent activity was based on the $\mathrm{IC}_{50}$ of rutin.

\section{The antioxidant activity of various extracts}

Figure 1 illustrates the reductive capabilities of rutin and quercetin. These calibration curves were used to calculate equivalent activity of various extracts related to rutin or quercetin (Figure 2). The equivalent activities of rutin and

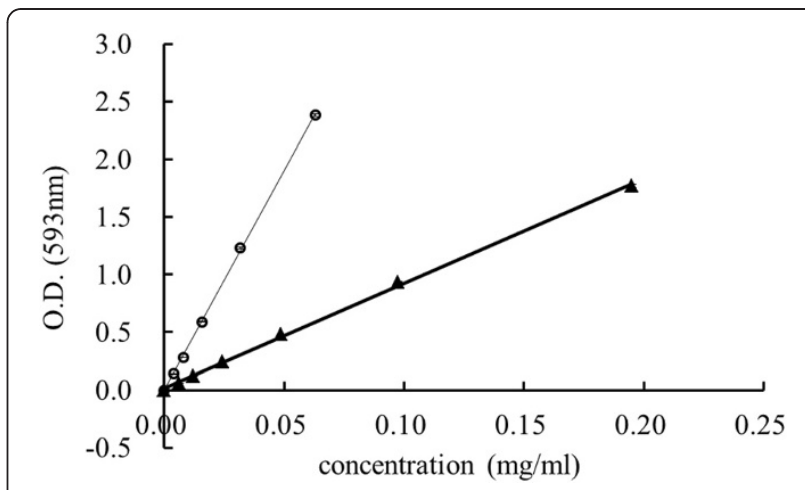

Figure 1 Dose-response lines for rutin $(\triangle)$ and quercetin $(O)$ solutions. Three replicates $(n=3)$ were performed for each concentration.

quercetin are perfect positive correlation (correlation $\mathrm{r}=1$ ) for 18 samples. Performing the FRAP assay is quick and simple, and the reaction is reproducible and linearly related to the weight concentration of the flavonoids. The crude extracts of tartary and common hulls extracted with $50 \%$ ethanol presented the greatest antioxidant activity. The activity per milligram of crude extract was equivalent to $0.23 \mathrm{mg}$ of rutin or $0.055 \mathrm{mg}$ of quercetin.

Table 1 The $I C_{50}$ of varied extracts for ACE inhibition

\begin{tabular}{|c|c|c|c|c|}
\hline Sample number & Portion of buckwheat & Extracting solvent & $\mathrm{IC}_{50}\left(\mu \mathrm{g} \mathrm{mL^{-1 } )}\right.$ & Equivalent activity to rutin \\
\hline 1 & Groats, common & Deionized water & $283( \pm 20)$ & 0.30 \\
\hline 2 & Groats, Tartary & Deionized water & $320( \pm 17)$ & 0.27 \\
\hline 3 & Groats, common & $20 \%(v / v)$ ethanol & $218( \pm 11)$ & 0.39 \\
\hline 4 & Groats, Tartary & $20 \%(v / v)$ ethanol & $237( \pm 35)$ & 0.36 \\
\hline 5 & Groats, common & $50 \%(v / v)$ ethanol & $286( \pm 1)$ & 0.30 \\
\hline 6 & Groats, Tatary & $50 \%(v / v)$ ethanol & $185( \pm 5)$ & 0.46 \\
\hline 7 & Plants, common & Deionized water & $629( \pm 71)$ & 0.14 \\
\hline 8 & Plants, Tatary & Deionized water & $989^{a}$ & 0.09 \\
\hline 9 & Plants, common & $20 \%(v / v)$ ethanol & $646( \pm 71)$ & 0.13 \\
\hline 10 & Plants, Tatary & $20 \%(v / v)$ ethanol & $895^{a}$ & 0.10 \\
\hline 11 & Plants, common & $50 \%(v / v)$ ethanol & $331( \pm 3)$ & 0.26 \\
\hline 12 & Plants, Tatary & $50 \%(v / v)$ ethanol & $313( \pm 18)$ & 0.27 \\
\hline 13 & Hulls, common & Deionized water & $424( \pm 35)$ & 0.20 \\
\hline 14 & Hulls, Tatary & Deionized water & $393( \pm 40)$ & 0.22 \\
\hline 15 & Hulls, common & $20 \%(v / v)$ ethanol & $117( \pm 2)$ & 0.74 \\
\hline 16 & Hulls, Tatary & $20 \%(v / v)$ ethanol & $168( \pm 19)$ & 0.51 \\
\hline 17 & Hulls, common & $50 \%(v / v)$ ethanol & $30( \pm 2)$ & 2.87 \\
\hline 18 & Hulls, Tatary & $50 \%(v / v)$ ethanol & $141( \pm 13)$ & 0.61 \\
\hline \multirow[t]{3}{*}{ control } & captopril & & 0.0019 & 45263 \\
\hline & quercetin & & 39 & 2.21 \\
\hline & rutin & & 86 & 1 \\
\hline
\end{tabular}

a: The concentration of $\mathrm{IC}_{50}$ is greater than the maximum dissoluble amount. Data were calculated from the linear regression analysis of logarithmic plots. 


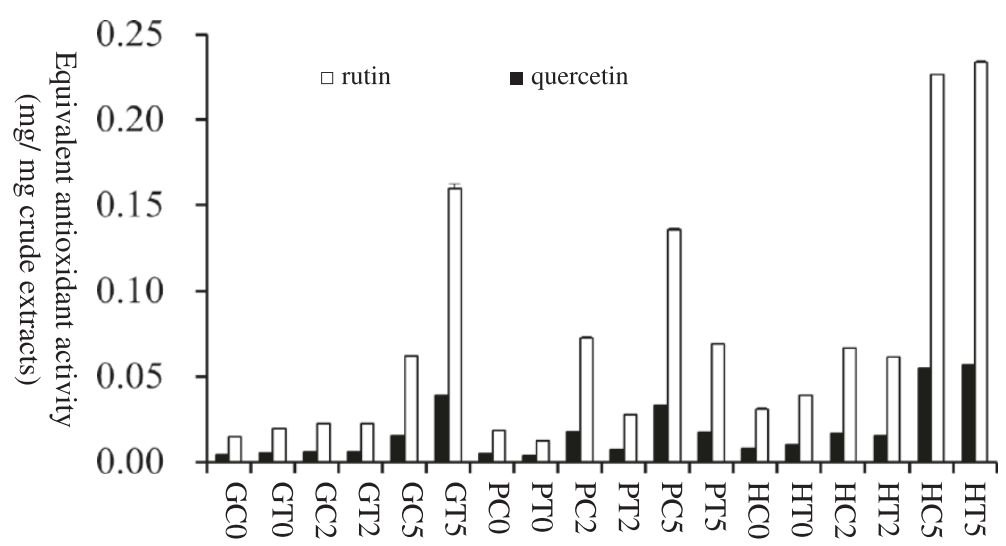

Figure $\mathbf{2}$ The equivalent antioxidant activity of various extracts $(\mathbf{n}=\mathbf{3})$. GCO is groats of common buckwheat extracted with deionized water. GT0 is groats of tartary buckwheat extracted with deionized water. GC2 is groats of common buckwheat extracted with $20 \%$ ethanol. GT2 is groats of tartary buckwheat extracted with 20\% ethanol. GC5 is groats of common buckwheat extracted with $50 \%$ ethanol. GT5 is groats of tartary buckwheat extracted with $50 \%$ ethanol. PCO is plants of common buckwheat extracted with deionized water. PT0 is plants of tartary buckwheat extracted with deionized water. PC2 is plants of common buckwheat extracted with 20\% ethanol. PT2 is plants of tartary buckwheat extracted with 20\% ethanol. PC5 is plants of common buckwheat extracted with 50\% ethanol. PT5 is plants of tartary buckwheat extracted with $50 \%$ ethanol. HCO is hulls of common buckwheat extracted with deionized water. HTO is hulls of tartary buckwheat extracted with deionized water. HC2 is hulls of common buckwheat extracted with 20\% ethanol. HT2 is hulls of tartary buckwheat extracted with $20 \%$ ethanol. HC5 is hulls of common buckwheat extracted with $50 \%$ ethanol. HT5 is hulls of tartary buckwheat extracted with $50 \%$ ethanol.

\section{Discussion}

By comparing the extracts of the various extracting solvents, we discovered that extracts obtained from $50 \% \mathrm{v} / \mathrm{v}$ ethanol solvent exhibited the greatest ACE inhibitory activity. We evaluated the ACE activity of various extracts using a paired $t$ test. The results showed that various ethanolic extracts presented significant differences of ACE inhibitory activities for all parts of the plant, except for the groats from common buckwheat, where the choice of solvent made no significant difference. Extracts from buckwheat plants (comprising stalks, stems, and leaves) showed poor ACE inhibitory activity for all solvents.

For the extracts with deionized water, groats presented optimal ACE inhibitory activity (lowest $\mathrm{IC}_{50}$ values), as compared to the plants and hulls. The ACE inhibitory activity of water-extracts could be caused by water-soluble peptides. This was consistent with the findings reported by Aoyagi et al. [16]. The buckwheat flour contained water-soluble peptides, which inhibited ACE activity. The 50\% ethanolic extract of common hulls produced the greatest inhibitory activity. The value of $\mathrm{IC}_{50}\left(30 \mu \mathrm{g} \mathrm{ml}^{-1}\right)$ was significantly lower than the $\mathrm{IC}_{50}$ values of other extracts. Li et al. [17] reported that proteins of tartary buckwheat flour treated with pepsin, followed by chymotrypsin and trypsin hydrolysis, resulted in an ACE inhibitory activity with $\mathrm{IC}_{50}$ at $140 \mu \mathrm{g} \mathrm{ml}^{-1}$. Therefore, ethanolic-soluble ingredients demonstrate an inhibitory activity that is superior to that of water-soluble ingredients.
Figure 3 shows the correlation plots of equivalent antioxidant activity and ACE inhibition. Comparing the rutin equivalent antioxidant activity and $\mathrm{ACE}$ inhibitory activity using the Pearson correlation showed that the correlation coefficient was 0.6 , indicating that the correlation between these 2 bioactivities was low to medium. Quercetin and rutin, which are 2 major types of flavonoids in buckwheat [20], presented great antioxidant activity. We evaluated the inhibitory effect of commercially available quercetin and rutin. The $\mathrm{IC}_{50}$ values were $39 \mu \mathrm{g} \mathrm{ml}^{-1}$ and $86 \mu \mathrm{g} \mathrm{ml}^{-1}$ for quercetin and rutin,

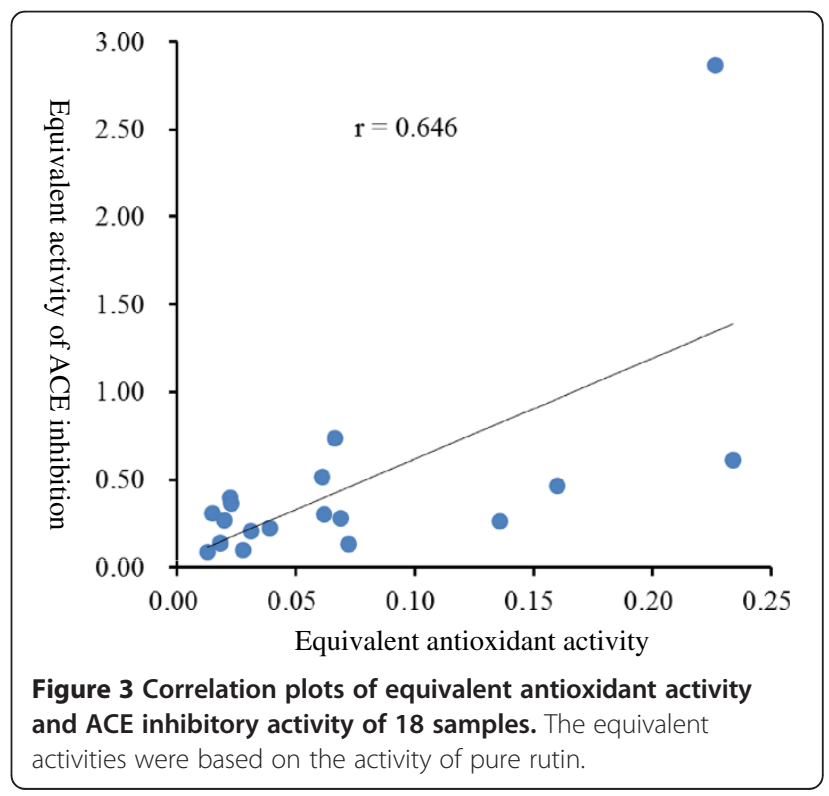


respectively. The antioxidant activity of crude extracts of common hulls per milligram was equivalent to $0.055 \mathrm{mg}$ of quercetin only; thus, the high ACE inhibitory activity of the crude extracts could be caused by other unidentified components in the extracts or by a synergistic effect of flavonoids, as suggested by Lacaille-Dubois et. al. [14].

However, the presence of strong in vitro activities does not necessarily imply that hull extracts can provide powerful anti-hypertensive and antioxidant drugs. These preliminary bioactive results of ethanolic extracts of common hulls warrant additional animal studies.

\section{Materials and methods Materials}

Captopril was obtained from ICN biomedical Inc. (Costa Mesa, CA, USA). Angiotensin-converting enzymes from porcine kidneys (EC 3.4.15.1), rutin hydrate, isoorientin, and quercetin anhydrous were purchased from Sigma (St. Louis, MO, USA). O-phthaldialdehyde reagent (OPA) containing OPA $\left(1 \mathrm{mg} \mathrm{ml}^{-1}\right)$ with 2-mercaptoethanol as a sulfhydryl moiety was obtained from Sigma. All chemicals were used without further purification.

Common buckwheat (Fagopyrum esculentum) and tartary buckwheat (Fagopyrum tataricum) were sown in autumn in Erlin Township, Changhua County, Taiwan. The grains were harvested approximately $100 \mathrm{~d}$ after sowing.

A microplate fluometric assay was measured using a Flex Station 3-microplate reader (Molecular Devices, Sunnyvale, CA, USA).

\section{Preparation of the extracts}

According to the regulations of the Department of Health, Taiwan, solvents extracted for functional foods or medicinal herbs may contain up to $50 \%(\mathrm{v} / \mathrm{v})$ ethanol. Thus, we extracted various buckwheat plant samples using 3 different solutions: deionized water; $20 \%$ (v/v) ethanol; and $50 \%(\mathrm{v} / \mathrm{v})$ ethanol, at $60^{\circ} \mathrm{C}$ for $2 \mathrm{~h}$.

The grains were dehulled manually and divided into groats and hulls. The buckwheat plants (comprising leaves, stems, and stalks), groats, and hulls were ground separately. Thirty-gram aliquots of each ground sample were extracted using $300 \mathrm{ml}$ of the various extracting solvents, under constant magnetic stirring in a $60^{\circ} \mathrm{C}$ water bath for $2 \mathrm{~h}$. After extraction, the slurry was filtered, and subsequently centrifuged at $5000 \mathrm{rpm}$ for $20 \mathrm{~min}$. The supernatant was collected and frozen at $-20^{\circ} \mathrm{C}$ and concentrated to dryness under reduced pressure. The dried crude extracts were stored at $-20^{\circ} \mathrm{C}$. Fresh solutions were prepared before each assay. The crude extracts were reconstituted using the respective extracting solvents, and then diluted to various concentrations using an ACE assay buffer.

\section{Angiotensin-I-converting enzyme inhibitory assay}

This study used a microplate fluometric assay modified according to the method proposed by Schwager et al. [21] to provide rapid screening and to consume fewer reagents. The fluorometric assay involved using the hydrolysis of hippuryl-L-histidyl-L-leucine (HHL) by ACE to form hippuric acid and histidyl-leucine (HL). Adding aqueous $\mathrm{NaOH}$ stopped the reaction. The product $\mathrm{HL}$ was reacted with OPA [22], and fluorescence was detected at an excitation of $365 \mathrm{~nm}$ and an emission of $460 \mathrm{~nm}$.

A lyophilized angiotensin-converting enzyme derived from porcine kidneys was reconstituted with an assay buffer to a concentration of $12.5 \mathrm{mU} \mathrm{ml}^{-1}$. The assay buffer ( $\mathrm{pH}$ 8.3) comprised potassium di-hydrogen phosphate $(0.1 \mathrm{M})$, di-sodium hydrogen phosphate $(0.1 \mathrm{M})$, and zinc chloride $(10.0 \mathrm{mM})$. A brief description of the assay is as follows: the ACE solution $(20 \mu \mathrm{l})$ was incubated using an assay buffer $(50 \mu \mathrm{l})$ containing HHL $(5.0 \mathrm{mM})$ and various concentrations of buckwheat extracts $(10 \mu \mathrm{l})$. The reaction was conducted at $37^{\circ} \mathrm{C}$ for $30 \mathrm{~min}$, and then stopped by adding aqueous $\mathrm{NaOH}(50$ $\mu \mathrm{l}, 1.0 \mathrm{M})$. An OPA reagent $(50 \mu \mathrm{l})$ was reacted with the HL produced from enzymatic hydrolysis for $10 \mathrm{~min}$, and fluorescence intensity was subsequently measured at $365 \mathrm{~nm}$ excitation and $460 \mathrm{~nm}$ emission. To correct for intrinsic fluorescence of $\mathrm{ACE}$ and the extracts, a blank was prepared by adding $\mathrm{NaOH}$ immediately after adding ACE, followed by adding HHL $(50 \mu \mathrm{l})$ and the extract solution $(10 \mu \mathrm{l})$.

The relative ACE activity was calculated as follows:

$$
\begin{aligned}
& \text { relative ACE activity } \% \\
& =\frac{\text { Flourescence intensity of inhibitory experiments }- \text { blank }}{\text { Flourescence intensity of } 100 \% \text { activity assay }- \text { blank }}
\end{aligned}
$$

The relative ACE activity\% versus the logarithmic concentrations was plotted. The concentration of $50 \%$ inhibition of ACE activity $\left(\mathrm{IC}_{50}\right)$ was determined for varied extracts by using linear regression analysis of logarithmic plots. We conducted at least 3 replicates for each extract.

\section{Ferric-reducing antioxidant power assay}

The antioxidant activities of the extracts were determined according to the procedures recommended by Benzie and Strain [23]. In brief, $40 \mu \mathrm{l}$ of flavonoidcontaining solutions were mixed in a 96-well plate with $300 \mu \mathrm{l}$ of a reagent solution containing $0.8 \mathrm{mM}$ of tripyridyltriazine and $1.7 \mathrm{mM}$ of $\mathrm{FeCl}_{3}$ in $300 \mathrm{mM}$ sodium acetate ( $\mathrm{pH}$ 3.6). The samples were incubated for $15 \mathrm{~min}$ at $37^{\circ} \mathrm{C}$, and the absorbance at $593 \mathrm{~nm}$ was recorded on a Flex Station 3-microplate reader. 


\section{Statistical analysis}

Statistical differences between the groups were evaluated using the $t$ test for paired data. The $p$-values were considered significant at $p<0.05$. We used Microsoft Excel ${ }^{\circledR}$ 2007 software for statistical analysis.

\section{Conclusion}

In conclusion, the findings showed that the ethanolic extract of hulls of common buckwheat presented powerful anti-hypertensive and antioxidant properties. It is worthy of further animal study and further investigation on components of the extract.

\section{Authors' contributions}

HY made substantial contributions to the conception and design, analysis and interpretation of data, and drafting and revision of the manuscript. HD performed the design and data collection of ACE inhibitory experiments. ST conducted the sample extraction. YH performed the FRAP assay. All authors read and approved the final manuscript.

\section{Acknowledgments}

This work was supported by the Taiwan Grains and Feeds Development Foundation and the National Science Council, Taiwan. We would like to thank two anonymous reviewers and the editor for their comments.

Received: 21 June 2012 Accepted: 28 June 2012

Published: 1 August 2012

\section{References}

1. Bonafaccia G, Marocchini M, Kreft I: Composition and technological properties of the flour and bran from common and tartary buckwheat. Food Chem 2003, 80:9-15.

2. Gawlik-Dziki U, Dziki D, Baraniak B, Lin R: The effect of simulated digestion in vitro on bioactivity of wheat bread with Tartary buckwheat flavones addition. LWT- Food Sci Technol 2009, 42:137-143.

3. Górecka D, Heś M, Szymandera-Buszka K, Dziedzic K: Contents of selected bioactive components in buckwheat groats. Acta Sci Polonorum, Technologia Alimentaria 2009, 8:75-83.

4. Holasova M, Fiedlerova V, Smrcinova H, Orsak M, Lachman J, Vavreinova S: Buckwheat-the source of antioxidant activity in functional foods. Food Res Int 2002, 35:207-211.

5. Jiang P, Burczynski F, Campbell C, Pierce G, Austria JA, Briggs CJ: Rutin and flavonoid contents in three buckwheat species Fagopyrum esculentum, F. tataricum, and F. homotropicum and their protective effects against lipid peroxidation. Food Res Int 2007, 40:356-364.

6. Kreft I, Fabjan N, Yasumoto K: Rutin content in buckwheat (Fagopyrum esculentum Moench) food materials and products. Food Chem 2006 98:508-512.

7. Liu B, Zhu Y: Extraction of flavonoids from flavonoid-rich parts in tartary buckwheat and identification of the main flavonoids. J Food Eng 2007, 78:584-587.

8. Ma Y, Xiong YL, Zhai J, Zhu H, Dziubla T: Fractionation and evaluation of radical scavenging peptides from in vitro digests of buckwheat protein. Food Chem 2010, 118:582-588.

9. Sun T, Ho C-T: Antioxidant activities of buckwheat extracts. Food Chem 2005, 90:743-749.

10. Suzuki T, Honda Y, Funatsuki W, Nakatsuka K: Purification and characterization of flavonol 3-glucosidase, and its activity during ripening in tartary buckwheat seeds. Plant Sci 2002, 163:417-423.

11. Zheng GH, Sosulski FW, Tyler RT: Wet-milling, composition and functional properties of starch and protein isolated from buckwheat groats. Food Res Int 1997, 30:493-502.

12. Zieliński H, Michalska A, Piskuła MK, Kozłowska H: Antioxidants in thermally treated buckwheat groats. Mol Nutr Food Res 2006, 50:824-832.

13. Campbell CG: Buckwheat. Fagopyrum esculentum Moench. Promoting the conservation and use of underutilized and neglected crops, Volume 19. Rome, Italy: The International Plant Genetic Resources Institute (IPGRI); 1997:23-25.
14. Lacaille-Dubois MA, Franck U, Wagner H: Search for potential Angiotensin Converting Enzyme (ACE)-inhibitors from plants. Phytomedicine 2001, 8:47-52.

15. Tsutsumi Y, Shimada A, Miyano A, Nishida T, Mitsunaga T: In vitro screening of angiotensin I-converting enzyme inhibitors from Japanese cedar (Cryptomeria japonica). J Wood Sci 1998, 44:463-468.

16. Aoyagi Y: An angiotensin-I converting enzyme inhibitor from buckwheat (Fagopyrum esculentum Moench) flour. Phytochemistry 2006, 67:618-621.

17. Li CH, Matsui T, Matsumoto K, Yamasaki R, Kawasaki T: Latent production of angiotensin I-converting enzyme inhibitors from buckwheat protein. J Pept Sci 2002, 8:267-274.

18. Ma MS, In YB, Hyeon GL, Yang CB: Purification and identification of angiotensin I-converting enzyme inhibitory peptide from buckwheat (Fagopyrum esculentum Moench). Food Chem 2006, 96:36-42.

19. Pihlanto-Leppala A, Rokka T, Korhonen H: Angiotensin I Converting Enzyme Inhibitory Peptides Derived from Bovine Milk Proteins. Int Dairy J 1998, 8:325-331.

20. Dietrych-Szostak D, Oleszek W: Effect of Processing on the Flavonoid Content in Buckwheat (Fagopyrum esculentum Moench) Grain. J Agric Food Chem 1999, 47:4384-4387.

21. Schwager SL, Carmona AK, Sturrock ED: A high-throughput fluorimetric assay for angiotensin I-converting enzyme. Nat Protoc 2006, 1:1961-1964.

22. Roth M: Fluorescence reaction for amino acids. Anal Chem 1971, 43:880-882.

23. Benzie IFF, Strain JJ: The Ferric Reducing Ability of Plasma (FRAP) as a Measure of "Antioxidant Power": The FRAP Assay. Anal Biochem 1996, 239:70-76.

doi:10.1186/1752-153X-6-78

Cite this article as: Tsai et al: Bioactivity comparison of extracts from various parts of common and tartary buckwheats: evaluation of the antioxidant- and angiotensin-converting enzyme inhibitory activities. Chemistry Central Journal 2012 6:78.

Publish with ChemistryCentral and every
scientist can read your work free of charge
"Open access provides opportunities to our
colleagues in other parts of the globe, by allowing
anyone to view the content free of charge."
W. Jeffery Hurst, The Hershey Company.
- available free of charge to the entire scientific community
- cited in PubMed and archived on PubMed Central
- yours - you keep the copyright
Submit your manuscript here:
http://www.chemistrycentral.com/manuscript/

